Deák, George. "Baczoni, Tamás, Tibor Balla et al. eds. 2014. A Nagy Háború, 1914-1918 - kézzelfogható hadtörténelem (The Great War, 1914-1918 - Tangible Military History]. Budapest: Zrínyi Kiadó, Honvédelmi Minisztérium Hadtörténeti Intézet és Múzeum munkatársai (Staff of the Institute and Museum of Military History Ministry of Defense). 68 pp. Two DVDs and fifty-six reproduced documentary inserts." Hungarian Cultural Studies. e-Journal of the American Hungarian Educators Association, Volume 10 (2017 DOI:

10.5195/ahea.2017.286

\title{
Baczoni, Tamás, Tibor Balla et al. eds. 2014. A Nagy Háború, 1914- 1918 - kézzelfogható hadtörténelem (The Great War, 1914-1918 - Tangible Military History]. Budapest: Zrínyi Kiadó, Honvédelmi Minisztérium Hadtörténeti Intézet és Múzeum munkatársai (Staff of the Institute and Museum of Military History Ministry of Defense). $68 \mathrm{pp}$. Two DVDs and fifty-six reproduced documentary inserts.
}

\section{Reviewed by George Deák*, Independent Scholar}

The change of regime in the entire East-European bloc after 1989 naturally brought with it a reappraisal of Hungarian twentieth-century history, and the current government has spent lavishly on the project of reconciling the average person to their family's past and thus encouraging patriotism and national pride. The World War I album at hand, intended to present the general public rather than scholars with a tangible overview of the war as experienced by the Hungarian people, may be seen as part of this effort. It is a collaborative work of over fifteen historians and museologists, some in military uniform and each dealing with a different aspect of the war's (hi)story. It is heartening to see that freedom was given to each to express his or her own interpretation, sometimes in implicit conflict with others in the team on some of the bigger questions such as the responsibility for the outbreak of war and for the disastrous peace-treaty following it.

The volume under review is one of three that were recently published in a similarly impressive format. The other two deal, respectively, with World War II and the 1956 Hungarian Revolution. The format of each volume is well suited to its purpose and each of them makes extensive use of the sophisticated museological and documentary resources of the publisher, the Institute and Museum of Military History, which is part of the Hungarian Department of Defense ['Hadtörténeti Intézet és Múzeum, HM']. Each volume is a multimedia artifact reminiscent of a photo album. In the present first volume, for example, each double page deals with an aspect or phase of the war, from the pre-war "Happy Peaceful Times" ['Boldog békeidök'] to "Grave Crosses and Cemeteries" ['Sírkeresztek és temetök']. Incidentally, no mention is made of the nonChristian war casualties, although, for example, Jews participated and died in the war in large numbers, contrary to the wide-spread stereotype of Jewish shirkers. Each such double-spread page contains an explanation of its topic, written by an expert, and is well illustrated with

*deakgy62@gmail.com

(cc) $\mathrm{Br}$

ULLS D-Serle
New articles in this journal are licensed under a Creative Commons Attribution 4.0 International License.

This journal is published by the University Library System of the University of Pittsburgh as part of its D-Scribe Digital Publishing Program and is cosponsored by the University of Pittsburgh Press 
Deák, George. "Baczoni, Tamás, Tibor Balla et al. eds. 2014. A Nagy Háború, 1914-1918 - kézzelfogható hadtörténelem (The Great War, 1914-1918 - Tangible Military History]. Budapest: Zrínyi Kiadó, Honvédelmi Minisztérium Hadtörténeti Intézet és Múzeum munkatársai (Staff of the Institute and Museum of Military History Ministry of Defense). 68 pp. Two DVDs and fifty-six reproduced documentary inserts." Hungarian Cultural Studies. e-Journal of the American Hungarian Educators Association, Volume 10 (2017) DOI:

10.5195/ahea.2017.286

photographs and inserts of various sorts: some in celophane pouches between the pages, some glued onto the pages as flaps or in accordion fashion, etc. Thus in their form, although far from that in their content and context, these tangible and effective techniques are reminiscent of sophisticated children's books.

The volume also contains two DVDs with a total of fifteen segments, each approximately fifteen minutes long and covering in interview or lecture format one of the thirty chapters or sections of the book, so one can assume that these anonymous chapters were written by the same historians and museologists who are featured and identified in the album's film segments. The DVDs also contain military marches and folk songs, as well as the anti-war poem written by Géza Gyóni (1884-1917), "If Only for One Night" ['Csak egy éjszakára']. In this poem the soldier-poet, who was wounded while defending the besieged Przemyśl Fort (in Modern Poland) and who later died in Russian captivity, invites with bitter sarcasm the speculators (yet interestingly not the politicians), whom he holds responsible for the war, to spend at least one night under fire. Finally, there are two wearable items: a replica of a soldier's dog-tag and a kerchief intended for the kaiserlich und königlich ("Imperial and Royal") joint Austro-Hungarian infantry replete with useful information about the war's weapons and its marching songs.

Some purchasers may browse through the book and put it on the coffee table. But the more curious among them can learn much about the war from the written and spoken words of an impressive array of scholars and from the documents they selected for presentation. These scholars include Ferenc Pollmann, the military historian who, together with Tibor Hajdu, coauthored an inclusive World War I study entitled A régi Magyarország utolsó háborúja, 19141918 ['The Last War of Old Hungary, 1914-1918'] and published in 2014 (Budapest: Osiris). Hajdu and Pollmann's study was reviewed in vol. 9 (2016) of this journal by Peter Pastor, who justly predicted that this study would become a classic (https://ahea.pitt.edu/ojs/index.php/ahea/article/view/247). Interestingly, in the DVD of the album at hand Pollman makes a counter-statement to the book's overall goal of promoting national pride, saying that "we Hungarians," meaning the political elite, "are the ones who blocked the reforms" that might have saved the Monarchy from dissolution" (DVD 1, "Boldog békeidők" ['Happy Peaceful times'], 12':50").

Still in the same segment dealing with the causes for the start of the war, the political and social historian Iván Bertényi Jr. points out that the domestic conflicts within the AustroHungarian Monarchy, whether between the Hungarians and other nationalities or among various Hungarian social and economic classes, were not the main cause for the outbreak of the war; rather, it was the wider set of conflicts among greater geo-political powers of Europe. Bertényi Jr. also reminds us that the average Hungarians, whether in the villages or in the towns and cities, were kept far from the political debates of the ruling classes. Thus, by implication he claims, and quite rightly so, that the war cannot be blamed on the common Hungarians. By contrast, the Hungarian ruling classes cannot be exonerated from the blame of bringing about the war since, along with the ruling classes of other European countries, and as part of the Austro-Hungarian Empire that forced the war against Serbia, these classes bear considerable responsibility for the outbreak of the war in July, 1914. This blame becomes even more evident if we consider the continuation of the war. The lonely efforts of politician Mihály Károlyi (1875-1955) to stop the 
Deák, George. "Baczoni, Tamás, Tibor Balla et al. eds. 2014. A Nagy Háború, 1914-1918 - kézzelfogható hadtörténelem (The Great War, 1914-1918 - Tangible Military History]. Budapest: Zrínyi Kiadó, Honvédelmi Minisztérium Hadtörténeti Intézet és Múzeum munkatársai (Staff of the Institute and Museum of Military History Ministry of Defense). 68 pp. Two DVDs and fifty-six reproduced documentary inserts." Hungarian Cultural Studies. e-Journal of the American Hungarian Educators Association, Volume 10 (2017) DOI:

10.5195/ahea.2017.286

war once it was evident that victory was unlikely were too little and too late, while the intransigent policy of Prime Minister István Tisza (1861-1918), whose statue has been recently restored next to the country's parliament, led to hundreds of thousands of unnecessary deaths. Curiously, though, these sins of commission and omission are passed over in this volume.

János Áder, the President of the Hungarian Republic as of 2012, claims in his Foreword to the album that the aim of this volume is not to evaluate World War I or to present a learned summary of its causes and consequences but rather to bring the suffering of the Hungarian people of that time closer to present-day readers and thus make us share their desire for peace; this is, indeed, a noble aim but not one that is strongly demonstrated by the material presented in this album. The volume, as can be expected from a military history, pays more attention to guns, cannons, aircrafts, submarines, storm troopers, uniforms, medals, and memorials to the heroic dead than it does to the horrors of trench warfare, the suffering of the wounded or the lasting pain of the bereaved relatives of approximately 660,000 dead from the territory of pre-war Hungary or, as we learn in this volume, of 350,000 to 380,000 ethnic Hungarians killed in the war. It is not that these issues are completely ignored but they are mentioned only in very broad outlines. As for other absences, no mention is made of the many desertions from the army, except for those at the very end of the war. The same omission is true concerning the atrocities committed by Austro-Hungarian forces against the local population, such as the August 17, 1914 massacre of civilians and perhaps non-uniformed guerillas at Šabac, Serbia, the remnants of which were reported with horror by Archduke Joseph, a general of the Austro-Hungarian forces who had arrived at the scene the following day (see p. 154 of Hajdu and Pollman's study cited earlier). We do learn about the living conditions and activities of Hungarian prisoners of war in the various countries where they were kept captive from the otherwise excellent summary of the section entitled "Hungarian Prisoners of War," but there is no mention of the approximately 60,000 ethnic Hungarian prisoners held in Russia, who ended up fighting for the Red Army and who, after returning to Hungary in 1919 or, if they were lucky enough to survive Stalin's purges, in 1945, spread communism in their homeland of Hungary.

The issue of anti-Semitism, just like that of the contribution and casualties of HungarianJewish soldiers in the war, is omitted in this volume. Yet, at least one expression of antiSemitism did make its way into it: one insert on p. 33 features a soldier's letter written on the backs of a bound set of post cards depicting the buildings of the military base of Hajmáskér at that time. In this letter, the writer complains about the poor army canteen and the high price of food outside the camp, for which he blames the "Jews" who allegedly had come down to the Balaton in the summer and eaten up everything in sight. But then, the date on this letter is August 10, 1920, meaning after the war and the Hungarian defeat in it, a time when such attitudes had already become even more widespread than during the war or before it. All this makes one wonder why this letter made its way into the album while any mention that Jews fought and died alongside Christians in this war did not.

This World War I album goes beyond the war to consider the defense of the country put up by the Red Army under the Soviet Republic in 1919, as well as "The Peace Diktat of Trianon, signed in 1920." The 1919 communist leadership is rightly blamed for its unpopular, overly zealous social and economic "bolshevization" of the country, which, along with the acceptance 
Deák, George. "Baczoni, Tamás, Tibor Balla et al. eds. 2014. A Nagy Háború, 1914-1918 - kézzelfogható hadtörténelem (The Great War, 1914-1918 - Tangible Military History]. Budapest: Zrínyi Kiadó, Honvédelmi Minisztérium Hadtörténeti Intézet és Múzeum munkatársai (Staff of the Institute and Museum of Military History Ministry of Defense). 68 pp. Two DVDs and fifty-six reproduced documentary inserts." Hungarian Cultural Studies. e-Journal of the American Hungarian Educators Association, Volume 10 (2017) DOI:

10.5195/ahea.2017.286

of the ultimatum for an armistice, undermined the military's until-then successful efforts to repulse the Czechoslovak and Romanian invading armies with a general mobilization of the lower classes, led by the experienced officer Aurél Stromfeld. In his DVD discussion of these events, Iván Bertényi Jr. speculates that the postwar short-lived communinst period probably led to an even greater loss of territory at Trianon than would otherwise have happened, but he gives no evidence for this highly contested assertion. More often than not war leads to unpredictable, generally dire consequences, and this important lesson was never absorbed by the Horthy regime throughout its more than two decades. Sorrowfully, nor is this lesson emphasized powerfully enough for the potential readership of this otherwise informative, illuminating and visually impressive World War I album. 